\title{
SYSTEMIC RESISTANCE INDUCED BY RHIZOSPHERE BACTERIA
}

\author{
L. C. van Loon, P. A. H. M. Bakker, and C. M. J. Pieterse \\ Department of Plant Ecology and Evolutionary Biology, Utrecht University, P.O. Box \\ 800.84, 3508 TB Utrecht, The Netherlands; e-mail: L.C.vanloon@bio.uu.nl
}

KEY WORDS: induced systemic resistance, plant growth-promoting rhizobacteria, salicylic acid, signaling pathways, systemic acquired resistance

\begin{abstract}
Nonpathogenic rhizobacteria can induce a systemic resistance in plants that is phenotypically similar to pathogen-induced systemic acquired resistance (SAR). Rhizobacteria-mediated induced systemic resistance (ISR) has been demonstrated against fungi, bacteria, and viruses in Arabidopsis, bean, carnation, cucumber, radish, tobacco, and tomato under conditions in which the inducing bacteria and the challenging pathogen remained spatially separated. Bacterial strains differ in their ability to induce resistance in different plant species, and plants show variation in the expression of ISR upon induction by specific bacterial strains. Bacterial determinants of ISR include lipopolysaccharides, siderophores, and salicylic acid (SA). Whereas some of the rhizobacteria induce resistance through the SA-dependent SAR pathway, others do not and require jasmonic acid and ethylene perception by the plant for ISR to develop. No consistent host plant alterations are associated with the induced state, but upon challenge inoculation, resistance responses are accelerated and enhanced. ISR is effective under field conditions and offers a natural mechanism for biological control of plant disease.
\end{abstract}

\section{INDUCTION OF RESISTANCE IN PLANTS}

\section{Systemic Acquired Resistance}

All plants possess active defense mechanisms against pathogen attack. These mechanisms fail when the plant is infected by a virulent pathogen because the pathogen avoids triggering or suppresses resistance reactions, or evades the effects of activated defenses. If defense mechanisms are triggered by a stimulus 
prior to infection by a plant pathogen, disease can be reduced. Induced resistance is a state of enhanced defensive capacity developed by a plant when appropriately stimulated $(47,48)$. Induced resistance is not the creation of resistance where there is none, but the activation of latent resistance mechanisms that are expressed upon subsequent, so-called "challenge" inoculation with a pathogen (96). Induced resistance occurs naturally as a result of limited infection by a pathogen, particularly when the plant develops a hypersensitive reaction. Although tissue necrosis contributes to the level of induced resistance attained, activation of defense mechanisms that limit a primary infection appears sufficient to elicit induced resistance (33). Induced resistance can be triggered by certain chemicals, nonpathogens, avirulent forms of pathogens, incompatible races of pathogens, or by virulent pathogens under circumstances where infection is stalled owing to environmental conditions. Generally, induced resistance is systemic, because the defensive capacity is increased not only in the primary infected plant parts, but also in non-infected, spatially separated tissues. Because of this systemic character, induced resistance is commonly referred to as systemic acquired resistance (SAR) $(80,82,89)$. However, induced resistance is not always expressed systemically: Localized acquired resistance (LAR) occurs when only those tissues exposed to the primary invader become more resistant (79). SAR and LAR are similar in that they are effective against various types of pathogens. A signal that propagates the enhanced defensive capacity throughout the plant in SAR appears to be lacking in LAR.

SAR is characterized by an accumulation of salicylic acid (SA) and pathogenesis-related proteins (PRs) $(38,82,89,95,102)$. Accumulation of SA occurs both locally and, at lower levels, systemically, concomitant with the development of SAR. Exogenous application of SA also induces SAR in several plant species $(29,82,97)$. Both pathogen- and SA-induced resistance are associated with the induction of several families of PRs. Induction of PRs is invariably linked to necrotizing infections giving rise to SAR, and has been taken as a marker of the induced state $(38,95,102)$. Some of these PRs are $\beta-1,3-$ glucanases and chitinases and capable of hydrolyzing fungal cell walls. Other PRs have more poorly characterized antimicrobial activities or unknown functions. The association of PRs with SAR suggests an important contribution of these proteins to the increased defensive capacity of induced tissues. Plants transformed with the $n a h G$ gene do not accumulate SA or PRs and do not develop SAR in response to necrotizing pathogens $(22,29)$. The $n a h G$ gene encodes salicylate hydroxylase, which converts SA into catechol, a product that does not induce resistance. Experiments with $n a h G$-transformed plants indicate that SA is an essential signaling molecule in SAR induced by necrotizing pathogens. 
Although SA may be transported from the primarily infected leaves, it does not appear to be the primary long-distance signal for systemic induction (96). So far, the nature of the signal has not been established (101), but the level of SAR is modulated by ethylene and jasmonic acid (JA) $(45,52,89,97,103,108)$. These results suggest that induction and expression of SAR are regulated through an interplay of several signaling compounds.

\section{Plant-Mediated Disease Suppression by Rhizobacteria}

Rhizosphere bacteria are present in large numbers on the root surface, where nutrients are provided by plant exudates and lysates $(66,81)$. Certain strains of rhizosphere bacteria are referred to as plant growth-promoting rhizobacteria (PGPR), because their application can stimulate growth and improve plant stand under stressful conditions $(40,65)$. Increased plant productivity results in large part from the suppression of deleterious micro-organisms and soilborne pathogens by PGPR (84). Fluorescent Pseudomonas spp. are among the most effective rhizosphere bacteria in reducing soil-borne diseases in diseasesuppressive soils (107), where disease incidence is low, despite the presence of pathogens and environmental conditions conducive to disease occurrence. These bacteria can antagonize soilborne pathogens through various mechanisms $(5,83)$. For example, bacterial siderophores inhibit plant pathogens through competition for iron, antibiotics suppress competing microorganisms, and chitinases and glucanases lyse microbial cells.

Studies on suppression of Fusarium wilt of carnation and radish, caused by Fusarium oxysporum f.sp. dianthi (Fod) and F. oxysporum f.sp. raphani (For), respectively, established competition for iron as the mechanism of disease reduction by $P$. putida strain WCS358 $(4,25,58,59,76)$. Under iron-limiting conditions in the rhizosphere, WCS358 secretes a pyoverdin-type siderophore (pseudobactin 358) that chelates the scarcely available ferric ion as a ferricsiderophore complex that can be transported specifically into the bacterial cell. Siderophores released by Fod or For under these circumstances are less efficient iron-chelators than pseudobactin 358, so iron available to the pathogens can become limiting in the presence of WCS358. Due to iron deficiency, fungal spore germination is inhibited and hyphal growth restrained, effectively lowering the chance that the plants become infected, and reducing disease incidence and severity. The plant, in contrast, does not appear to suffer from iron shortage (26). A bacterial mutant generated by $T n 5$ transposon mutagenesis and unable to produce pseudobactin $358\left(\mathrm{WCS} 358 \mathrm{Sid}^{-}\right.$) did not reduce disease incidence (25). A different bacterial strain, Pseudomonas fluorescens WCS417, was about twice as effective as WCS358 in suppressing fusarium wilt in carnation. However, a $\mathrm{Sid}^{-}$mutant of this strain was as effective as the wild type in suppressing the disease (28). Clearly, a mechanism other than 
competition for iron was responsible for protecting carnation against fusarium wilt by WCS417. When WCS417 and Fod were applied to different parts of carnation plants by treating the roots with the bacterium and introducing the fungus one week later in the stem by slashing, a similar disease reduction was obtained (98). The bacterial strain and fungal pathogen remained spatially separated, indicating that WCS417 protected carnation against Fod by a plant-mediated mechanism. Heat-killed WCS417 proved as effective in suppressing disease as were live bacteria (99), confirming that the protective effect is plant-mediated. Similar results were obtained when radish root tips were treated with $P$. fluorescens strains WCS417 or WCS374 and For was inoculated on the root base (55). These observations established that selected strains of nonpathogenic rhizobacteria can suppress disease by inducing resistance in plants. This induced resistance has been termed "induced systemic resistance" (ISR) $(42,73)$.

\section{RHIZOBACTERIA-MEDIATED INDUCED SYSTEMIC RESISTANCE}

\section{Induced Systemic Resistance as the Mechanism of Disease Suppression}

SAR has been documented in multiple plant species (33), whereas studies of ISR by rhizosphere bacteria have concentrated so far on a few species. Notably, no ISR has yet been reported in monocotyledons. The available data on plant species in which rhizobacteria-mediated ISR has been reported are summarized in Table 1.

Common procedures to accomplish induced resistance are pouring a suspension of the bacteria on, or mixing it with, autoclaved soil; dipping the roots of seedlings in a bacterial suspension at transplanting; or coating seeds with high numbers of bacteria before sowing (39). Subsequently, seedlings are challenged with a pathogen. Because rhizobacteria are present on the roots, systemic protection against root pathogens must be demonstrated by applying the inducing bacteria to one part of the root system and the challenging pathogen to another part, for instance by making use of split-root systems. Testing for protection against foliar pathogens is easier, because the pathogens are naturally separated from the rhizobacteria. However, rhizobacteria applied to seeds, or to soil into which seeds are sown or seedlings are transplanted, can move into the interior of aerial plant tissues and maintain themselves to some extent on the exterior of aerial surfaces $(44,50)$.

Because many rhizobacteria triggering ISR can also inhibit growth of a pathogen directly, their capacity to suppress disease may involve more than one mechanism. Thus, in order to prove that resistance is induced and that 
it is truly systemic, it must be shown that inducing rhizobacteria are absent from the site of challenge with the pathogen and that the inducing bacterium and the challenging pathogen remain spatially separated for the duration of the experiment. Many studies in which induced resistance is considered as the mechanism responsible for disease reduction have not specifically addressed this point, leaving the involvement of other mechanisms open to question. For example, treatment of bean seeds with $P$. fluorescens $\mathrm{S} 97$ reduced the number of lesions due to halo blight to $17 \%$ of that in nontreated controls (1). Protection was eliminated when the bacterial suspension was autoclaved, indicating a need for live bacteria for protection to be achieved. Whether the disease suppression resulted from antagonism or from ISR is not clear, because absence of the antagonistic bacteria from the aerial parts of the plants was not checked. Yet, even though conclusive evidence may be lacking, induced resistance can be an important consequence of tissue colonization with specific nonpathogenic bacteria or fungi (37).

In analyses of $P$. aeruginosa 7NSK2-induced resistance in bean against gray mold (19), P. fluorescens WCS417-mediated protection of carnation against Fusarium wilt (98) and resistance in cucumber against anthracnose induced by any of six PGPR (104) stems, petioles, cotyledons and/or leaf extracts were free from, or contained at most a negligible quantity of, inducing bacteria, implying involvement of ISR. When spontaneous rifampicin-resistant mutants were used for treating seeds, some strains were recovered from inside surfacedisinfested roots. However, none of the inducing strains was found in leaves used for challenge. Upon injection of cucumber cotyledons $P$. putida 89B-27 and Serratia marcescens $90-166$ multiplied in the tissue but were not recovered from stems 1 or $2 \mathrm{~cm}$ above or below the cotyledons (62). Thus, while some bacteria that induce systemic resistance colonize internal tissues, they do not appear to establish themselves on challenged leaves, suggesting that neither competition nor antibiosis is involved in disease suppression $(104,105)$.

In studies on protection of cucumber against diseases caused by soilborne fungi $(61,113)$ split-root assays were used in which the inducing bacteria and the pathogen were simultaneously inoculated on separate halves of seedling roots, and then planted in separate pots. ISR was expressed as delayed symptom development, reduced disease severity, and reduced disease incidence compared to nonbacterized controls. Movement of inducing bacteria was monitored by using a bioluminescent transformant, that was detected with a charge-coupled device camera. The bacteria showed only limited movement within inoculated pots and did not migrate to the pots in which the pathogen was inoculated, demonstrating that the PGPR and pathogen remained spatially separated (61).

ISR in radish against Fusarium wilt was demonstrated in a bioassay involving rock wool wetted with nutrient solution (55). Seedlings were placed 


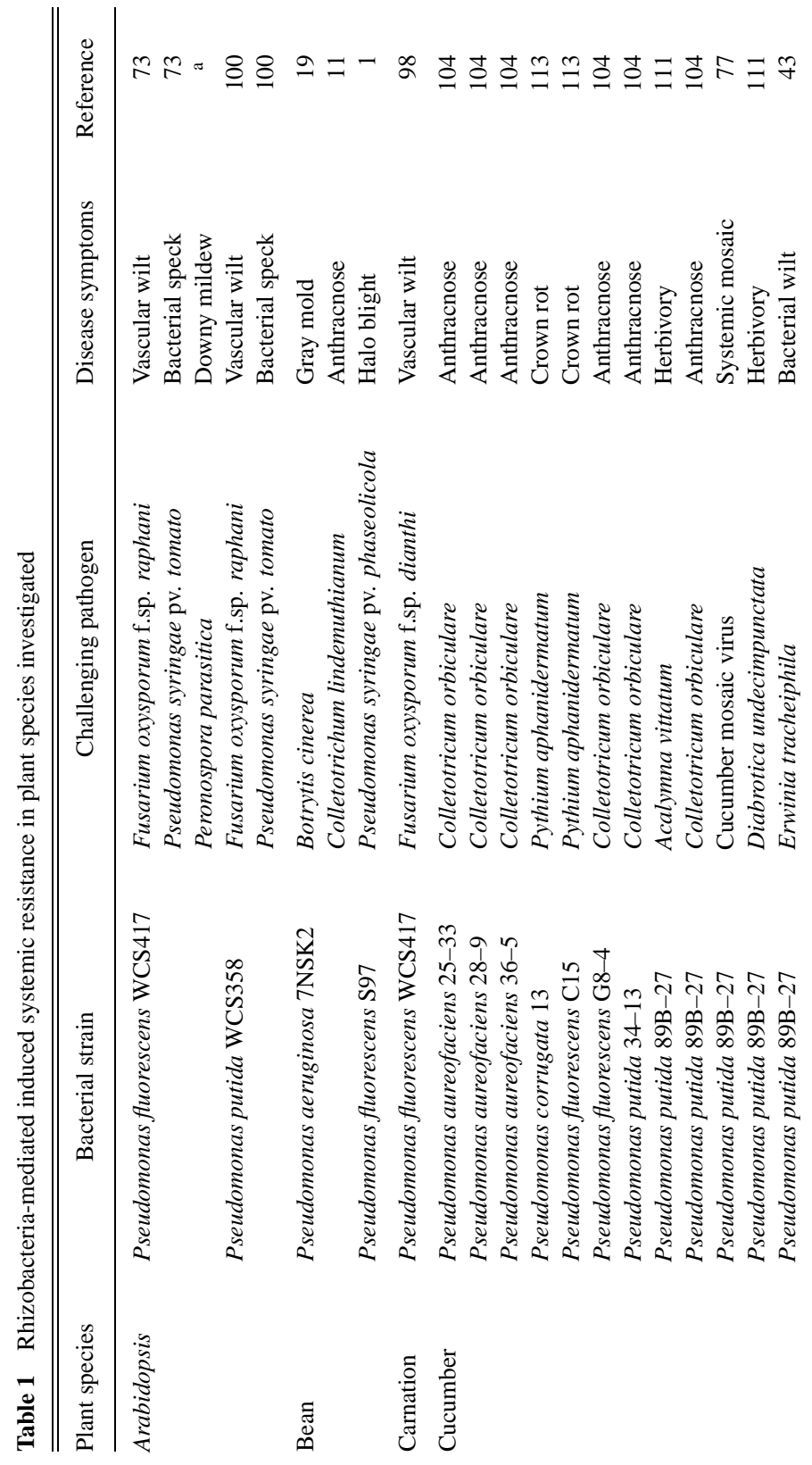




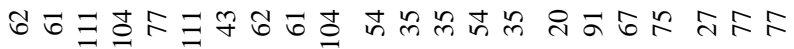
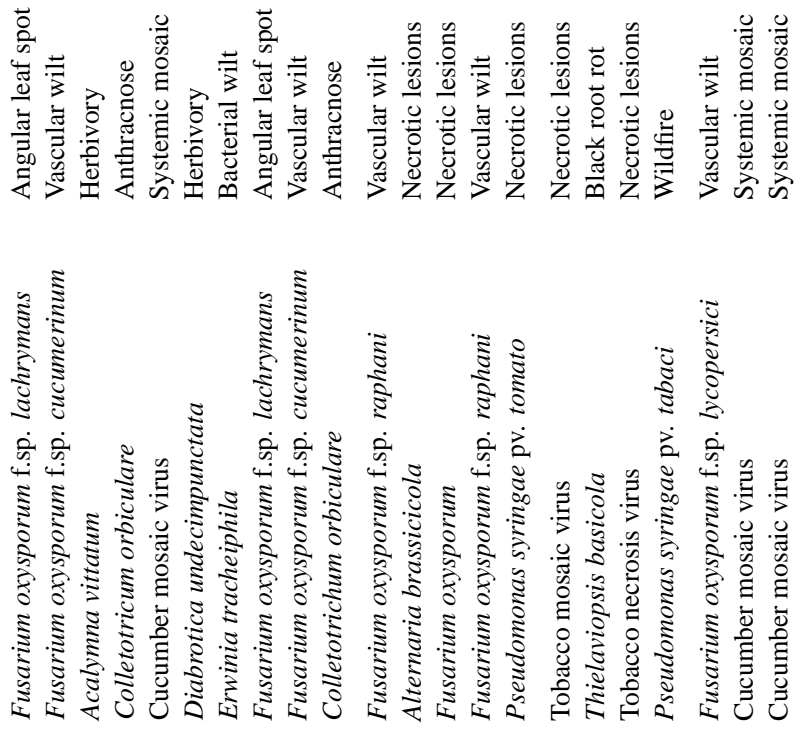

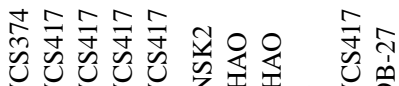

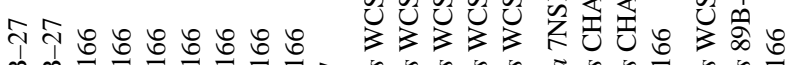
مै

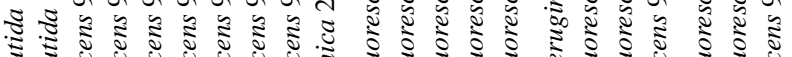

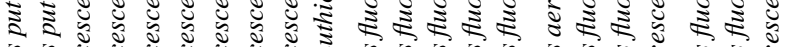

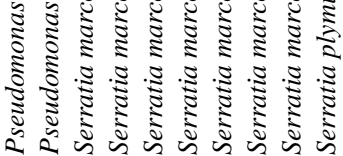

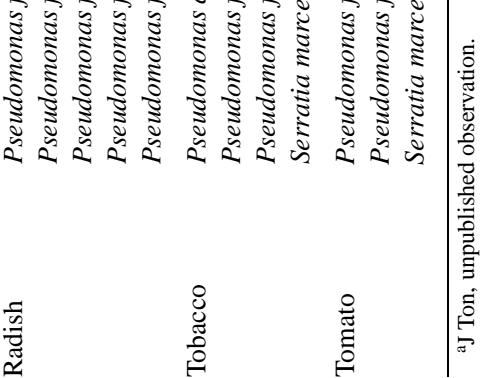


horizontally on rock wool cubes with the distal part of the roots on cubes contained in a plastic bag, adjacent to another bag with cubes supporting the proximal part of the root system. The roots were laid down through an incision in the bags. The distal part of the roots was then treated with a bacterial suspension in talcum emulsion. Two to three days later, the proximal part of the root system was inoculated with the fungal pathogen. Bacterial colonization of the root remained confined to the distal portion of the root and no fungus was recoverable from this part, demonstrating that the bacteria remained spatially separated from the pathogen for the duration of the experiments.

\section{Criteria for Induction of Systemic Resistance}

In those investigations where rhizobacteria-mediated ISR and pathogen-induced SAR were compared directly $(35,62,67,73,100)$, the level of disease suppression was similar. It can be concluded, therefore, that rhizobacteria-mediated ISR is a generally occurring phenomenon resembling pathogen-induced SAR. Although SAR induction is not dependent on the development of a hypersensitive reaction (96), it is maximally expressed when the inducing pathogen causes necrosis (14). In contrast, inducing rhizobacteria typically do not cause any visible symptoms on the host, and commonly enhance plant growth $(40,65)$. Steiner \& Schönbeck (88) formulated criteria for the verification of SAR, to distinguish induced resistance from other mechanisms that can reduce disease incidence or severity. These criteria are useful in comparing the characteristics of rhizobacteria-mediated ISR to SAR.

1. Absence of toxic effects of the inducing agent on the challenging pathogen. This criterion rules out any direct antagonistic effects of the inducer's metabolites on the pathogen and pertains specifically to bacterially produced antibiotics. It is difficult to establish unequivocally ISR when the inducing bacterium produces a metabolite that inhibits the pathogen. Even when the inducing organism is shown not to be present at the site of challenge with the pathogen, a metabolite produced by a rhizobacterium could be transported through the plant, inhibiting the pathogen directly. Although induced resistance was inferred in the suppression of halo blight on bean by P. fluorescens S97, the rhizobacterium exhibited bacteriostatic activity against the bean pathogen (1). P. fluorescens S97 might produce substances on the surface of germinating seeds that are taken up and translocated to the foliage. Concentrations of these inhibitory compounds might become high enough to restrict multiplication of the pathogen or even could, in themselves, also induce resistance. Some antibiotics produced by rhizobacteria, such as 2,4-diacetylphloroglucinol (DAP) or phenazine-1-carboxylic acid (PCA), are toxic to plants at high concentrations (68) and could induce SAR in the same way as a pathogen causing 
localized necrosis. P. fluorescens CHA0, a PGPR strain with multiple mechanisms of disease suppression (67), behaves as an endophyte and produces several toxic metabolites, including DAP, pyoluteorin and hydrogen cyanide (68). These antibiotics can affect tobacco plants, perhaps resulting in the induction of stress-related defense responses. A derivative of CHAO that overproduces DAP and pyoluteorin protected tobacco roots significantly better than did the wild type against black root rot, caused by Thielaviopsis basicola, but at the same time drastically reduced plant growth. CHA0 was seldom found in contact with the mycelium of T. basicola and, when in direct contact with the pathogen, CHAO did not affect the physical integrity of the fungal hyphae. Although pyoluteorin and DAP suppress black root rot through inhibition of $T$. basicola, there was no correlation between the sensitivity of various pathogens to the antibiotics and the degree of disease suppression achieved by the bacterium. Antibiotic overproduction affected neither the protection of wheat against Pythium ultimum or Gaeumannomyces graminis var. trit$i c i$, nor the growth of wheat plants. In contrast, the overproducing derivative of CHA0 showed an increased capacity to protect cucumber against $F$. oxysporum f.sp. cucumerinum and Phomopsis sclerotioides, compared with the wild-type strain (68). Presumably, secondary metabolites that inhibit T. basicola directly could also induce resistance of tobacco roots against the disease (91).

The best evidence for PGPR-mediated ISR is obtained when the rhizobacterium does not antagonize the pathogen in culture. For instance, out of six strains initially found to induce systemic resistance in cucumber against anthracnose, five did not inhibit the causal pathogen Colletotrichum orbiculare on three culture media (104). Even when inhibition is not observed in culture, however, direct inhibition of a pathogen in the rhizosphere cannot be excluded because conditions in the rhizosphere differ from those on artificial media, and an antibiotic produced exclusively in planta may go undetected.

2. Suppression of the induced resistance by a previous application of specific inhibitors, such as actinomycin D (AMD), which affect gene expression of the plant. This criterion is difficult to apply to ISR mediated by rhizobacteria because inhibitors of plant metabolism affect many processes besides activation of defense mechanisms. Eukaryotic fungi will be perturbed in the same way as plants when inhibitors of DNA-dependent RNA- or protein synthesis are employed. Inhibition of prokaryotic protein synthesis affects bacteria, as well as plastids and mitochondria. This criterion appears most useful if RNA viruses are the challenging pathogens, because these viral pathogens are insensitive to AMD. However, only a few studies have employed viruses as challenging pathogens for testing rhizobacteria-mediated ISR $(20,67,77)$. 
3. Necessity of a time interval between application of the inducer and the onset of protection in the plant. The plant needs time to reach the induced state. An immediate effect of application of an inducer on plant protection is unlikely to result from an increase in the plant's general defensive capacity. Many studies have shown that it generally takes from a few days to a week for SAR or ISR to develop (33). In the elicitation of ISR mediated by P. fluorescens WCS374 against Fusarium wilt of radish, at least one day was necessary after application of the bacteria for significant resistance to be induced (55). A contrasting example is provided by PGPR strains $P$. corrugata 13 and $P$. fluorescens $\mathrm{C} 15$, which induced systemic resistance in cucumber against crown rot caused by Pythium aphanidermatum (113). The PGPR strains were applied to one half of a split-root system spatially separated from pathogeninoculated roots. Occurrence of stem rot was delayed and disease index was reduced, but application of the bacteria 1 week before inoculation with the fungus did not reduce disease to the same degree as when both were inoculated at the same time. This result is puzzling in view of the time typically needed to induce ISR and its maintenance thereafter. The possibility that the rhizobacteria produced antifungal metabolites that were transported to the opposite root system was discounted on the grounds that these bacterial isolates did not inhibit mycelial growth of $P$. aphanidermatum in culture.

\section{Absence of a typical dose-response correlation known for toxic components.} Resistance is commonly induced only when plants are inoculated with a dosage of bacteria that exceeds a threshold population size. No increase in resistance is evident when the dosage of bacteria is increased further $(55,76)$. SAR, once induced, is often maintained for the lifetime of the plant and although the level of resistance expressed diminishes during plant growth, induced leaves remain resistant up to an advanced stage of senescence $(13,49)$. This implies that the inducing agent does not need to be present for the lifetime of the plant. A limited period in which the population size of the inducing bacterium is above the required threshold is sufficient to induce ISR, which then remains active even if the population of the inducer dwindles. This contrasts with disease suppression mediated through direct inhibition of a pathogen, where the population size of an antagonist must remain high as long as the pathogen poses a threat to the plant.

When P. putida 89B-27 or S. marcescens 90-166 were inoculated on cucumber seeds prior to planting and plants were then challenged with $C$. orbiculare, 89B-27 reduced mean total lesion diameter up to $60 \%$, whereas 90-166 was often significantly less effective. Populations of 89B-27 declined at a consistent rate over time, dropping from over $10^{8} \mathrm{cfu}^{\mathrm{g}} \mathrm{g}^{-1}$ root 1 week after planting to $10^{3} 3$ weeks later. ISR was evident at the first-leaf stage, increased over 
time, and was maintained at least to the fifth-leaf stage more than 5 weeks after sowing. Population dynamics of 90-166 were similar to those of 89B-27. ISR was somewhat more variable but was generally observed at all leaf stages. Although population densities of the two strains declined on the roots, ISR persisted, supporting the notion that, once induced, systemic resistance in the plant is maintained (63).

At least $10^{5}$ cfu.g ${ }^{-1}$ root of P. putida WCS358 is required to suppress For through siderophore-mediated competition for iron, and this population must be maintained for sustained disease suppression. P. fluorescens WCS374 and WCS417 can also suppress Fusarium wilt of radish by inducing systemic resistance. Also $10^{5} \mathrm{cfu}^{-\mathrm{g}^{-1}}$ of the root bacteria was required for induction of ISR, and no disease suppression was evident when rhizosphere colonization by WCS374 or WCS417 of the roots did not reach this level (55). However, no relationship was apparent between disease incidence at later stages and the remaining rhizosphere population densities $(35,76)$. Thus, the initial triggering of the plant leads to its induced state and, once this has been reached, further protection is independent of the remaining population of the inducing bacterium in the rhizosphere.

5. Nonspecificity of protection. SAR constitutes an enhanced defensive capacity against fungi, bacteria, and viruses, as well as occasionally against insects and nematodes. If rhizobacteria-mediated ISR is similar to SAR, ISR should also protect against these different types of organisms.

Resistance induced by $P$. fluorescens WCS417 in radish is effective against Fusarium wilt, and reduces necrotic lesion formation caused by the avirulent bacterial pathogen Pseudomonas syringae pv. tomato (Pst), and the avirulent fungal leaf pathogens Alternaria brassicicola and a different isolate of $F$. oxysporum. The same results were obtained when the inducing rhizobacterium was applied spatially separated on the roots, or to a single leaf different from the ones used for challenge inoculation (35). WCS417 also induces resistance against Rhizoctonia root rot, but only if inoculum densities of the causal pathogen $R$. solani were relatively low (PAHM Bakker, P Vogel, unpublished observations).

In cucumber, diseases caused by two fungi, the root-infecting Fusarium oxysporum f.sp. cucumerinum and the foliar pathogen $C$. orbiculare, and two leaf-spotting bacteria, Pseudomonas syringae pv. lachrymans and Erwinia tracheiphila, are suppressed by the same PGPR strains through the induction of systemic resistance (Table 1). These results indicate that rhizobacteria-mediated ISR, like SAR, is effective against multiple diseases. Moreover, two recent reports describe that cucumber plants growing from PGPR-treated seeds in the field supported lower numbers of the spotted cucumber beetle, Diabrotica 
undecimpunctata, and the striped cucumber beetle, Acalymna vittatum (110, 111). PGPR treatment resulted in greater beetle control than did weekly applications of insecticide. As a result cucumber plant growth and yield were enhanced significantly by inoculation with PGPR. The inducing bacteria appeared to reduce the level of the secondary compound cucurbitacin in the plants, which acts as a feeding stimulant to the beetles. This observation is particularly interesting because it shows that induction of systemic resistance by these PGPR is associated with a defined change in plant metabolism.

6. Local as well as systemic protection. As discussed previously, induced resistance is not necessarily systemic. However, in the presence of inducing rhizobacteria that may also have antagonistic properties, local protection as a result of induced resistance is difficult to verify experimentally. Mutants of the pathogen that are insensitive to antagonism can aid in resolving this issue. In the development of SAR, a mobile signal is generated, transported from the site of induction both upward and downward in the plant, and generates the induced state in distant tissues $(33,80)$. Triggering of ISR by rhizobacteria similarly produces a translocatable signal that induces protection in both roots and shoots.

7. Dependence on the plant genotype. This criterion presupposes significant differences in the level and type of resistance in different cultivars. Although little information is available in the case of SAR, genotype-specific variation in the level of resistance can be expected if induced resistance constitutes an enhancement of the extant defensive capacity (96).

Cultivar specificity of ISR in cucumber against anthracnose was studied in one resistant and three susceptible cultivars. P. putida 89B-27 induced systemic resistance in all three susceptible cultivars, whereas $S$. marcescens 90-166 did so in only two cultivars. Both strains failed to increase resistance of the resistant cultivar. No cultivar specificity in root colonization patterns of the two strains was observed, so the failure of the strains to enhance protection of the resistant cultivar could not be explained by poor root colonization (63). Apparently, resistance in the already genetically resistant cultivar could not be further enhanced by the PGPR (63). These data indicate that plant cultivars differ in their inducibility by rhizobacteria.

In carnation, $P$. fluorescens WCS417 reduced incidence of Fusarium wilt in the moderately resistant carnation cultivar Pallas and less consistently in the susceptible cultivar Lena. These results likewise support the criterion that genetically determined differences in the level of PGPR-mediated ISR occur in different cultivars, and confirm that the extant defensive capacity is enhanced when induced resistance is expressed. In contrast, no genetic differences in inducibility were observed in radish (55). P. fluorescens WCS374 induced a 
similar level of resistance against Fusarium wilt in six cultivars ranging from highly susceptible to relatively resistant, provided that fungal inoculum density was adjusted to levels that cause $40 \%$ to $80 \%$ disease incidence in nonbacterized control plants. At higher inoculum doses of the pathogen, ISR apparently was insufficient to reduce disease development; and at lower disease incidence, the effect of the inducing bacteria was too small to be significant. Differences in inducibility would have been recorded, however, if all cultivars had been inoculated with the same dose of the fungus.

\section{BACTERIAL DETERMINANTS OF INDUCED SYSTEMIC RESISTANCE}

Table 2 summarizes the current status with regard to the bacterial determinants of induced systemic resistance.

\section{Lipopolysaccharide}

In the systemic protection of carnation against Fusarium wilt by $P$. fluorescens WCS417, heat-killed bacteria or the purified bacterial outer membrane lipopolysaccharide (LPS) were as effective in inducing resistance as were live bacteria (99). This observation indicated that the bacterial LPS acts as a determinant of resistance induction by WCS417 in carnation.

Also in radish, the bacterial LPS appeared to be the trait responsible for resistance induction (56). Cell wall extracts of P. fluorescens WCS374 or WCS417,

Table 2 Bacterial determinants and types of systemic induced resistance

\begin{tabular}{llcc}
\hline \hline \multicolumn{1}{c}{ Bacterial strain } & Plant species: bacterial determinant & Reference & Type \\
\hline $\begin{array}{l}\text { Pseudomonas aeruginosa } \\
\text { strain 7NSK2 }\end{array}$ & Tobacco: salicylic acid & 20 & SAR \\
& Bean: salicylic acid & 19 & SAR \\
Pseudomonas fluorescens & Tobacco: siderophore & 67 & SAR \\
CHAO & Radish: lipopolysaccharide & 55 & ISR \\
WCS374 & siderophore & 57 & \\
& iron-regulated factor & 57 & \\
WCS417 & Carnation: lipopolysaccharide & 99 & ISR \\
& Radish: lipopolysaccharide & 55 & ISR \\
& iron-regulated factor & 57 & \\
Arabidopsis: lipopolysaccharide & 100 & ISR \\
Pseudomonas putida & Arabidopsis: lipopolysaccharide & a & ISR \\
WCS358 & siderophore & a & \\
& & & \\
\hline
\end{tabular}

aPAHM Bakker, I Van der Sluis, unpublished observations. 
or purified LPS consisting of lipid A-inner core-O-antigenic side chain (OA), were as effective as live bacteria when applied to radish roots. Bacterial mutants lacking the $\mathrm{O}$-antigen $\left(\mathrm{OA}^{-}\right)$, as well as their cell wall extracts, were ineffective. These results rule out any protective effects resulting from bacterial metabolism and show that the specificity within the structure of the $\mathrm{O}$-antigenic side chain of the LPS determines the induction of systemic resistance by these rhizobacteria. The resistance-inducing OA of WCS374 was effective not only on roots, but also when applied to the cotyledons. Hence, the plant is able to perceive OA not only at the root surface, but also at the leaf surface.

In tomato, the level of resistance induced by WCS417 against Fusarium wilt caused by F. oxysporum f.sp. lycopersici (24) likewise appeared related to the presence of the OA of the LPS (27).

Bacterial LPS contributes to growth and survival of the bacteria in planta by aiding in colonization, creating a favorable micro-environment, acting as a barrier to plant defensive compounds, and by modulating host reactions (72). Inoculation of tobacco plants with purified LPS from a number of bacteria can prevent the hypersensitive response to incompatible bacteria and reduce symptoms in compatible interactions $(31,69)$. However, the mechanism involved is unknown.

\section{Siderophores}

The O-antigenic side chain of LPS was a major determinant of ISR under ironreplete conditions, but under iron-limiting conditions, $\mathrm{OA}^{-}$mutants of $P$. fluorescens WCS374 and WCS417 were not impaired in their ability to induce resistance in radish against Fusarium wilt (54). These results indicated that (an)other bacterial determinant(s) expressed only under low-iron conditions also induced resistance. Because siderophores are produced by bacteria under these conditions, the pyoverdin-type pseudobactins of three WCS strains were isolated and applied to radish roots. The purified siderophore of WCS374 induced resistance to the same level as the bacterial LPS. In contrast, the siderophore of WCS417 did not induce ISR, and neither did the siderophore of $P$. putida WCS358, a strain that does not induce resistance. The pseudobactin-type siderophores of all three strains have similar affinities for ferric iron. Therefore, the possibility that the pseudobactin produced by WCS374 acts nonspecifically by inducing limited iron stress in the plant can be discounted.

The Sid ${ }^{-}$mutants of both WCS374 and WCS417 induced stronger resistance under conditions of iron deficiency than in the presence of excess iron, and again to a level similar to that reached upon application of the wild type bacteria. The pseudobactin of WCS374 can induce resistance, but it did not seem to be responsible for ISR caused by WCS374 under low-iron conditions. Apparently, different bacterial determinants can induce systemic resistance in radish, but 
their effects seem complementary rather than additive and full induction by one factor masks any contribution by the other(s) (54).

Several resistance-inducing bacteria can produce SA as a siderophore under iron-limiting conditions in culture $(19,20,54,71)$. Because siderophoremediated competition for iron occurs in the rhizosphere $(4,20,64)$, it must be inferred that iron limitation commonly occurs around plant roots, making it likely that bacteria can produce SA at the root surface. Both WCS374 and WCS417 produce SA at about 50 and $10 \mu \mathrm{g} \mathrm{ml}^{-1}$, respectively, in standard succinate medium (SSM) (54). The production of SA decreases rapidly with increasing iron concentration in SSM medium. Strain WCS358 did not induce resistance in radish against Fusarium wilt under low-iron conditions, and did not produce SA in culture. SA induced resistance in radish against Fusarium wilt when applied to roots at concentrations as low as $100 \mathrm{fg} \mathrm{g}^{-1}$ talcum emulsion. Indeed, the capacity of WCS374 and WCS417 to produce SA in culture was consistent with their ability to trigger ISR of radish grown under low-iron conditions.

WCS374 has the largest capacity to produce SA, so SA production in this strain was studied in detail. A gene bank was constructed in a cosmid vector and mobilized into the WCS358 $\mathrm{Sid}^{-}$mutant, which does not produce SA or the pseudobactin siderophore (70). Screening led to the identification of a cosmid containing $28 \mathrm{~kb}$ of genomic DNA from WCS374; a 5-kb EcoR1 fragment contained therein was sufficient to confer SA production on WCS358 $\mathrm{Sid}^{-}$. Sequencing of the 5-kb fragment revealed it to be part of an iron-regulated operon containing open reading frames homologous to the SA biosynthetic genes of $P$. aeruginosa (85), as well as to genes involved in a pathway from isochorismate to (a) siderophore(s) of the enterobactin type. When the cosmid containing the entire $28 \mathrm{~kb}$ of genomic DNA was transferred into the WCS358 $\mathrm{Sid}^{-}$recipient, a novel siderophore fluorescing blue-green under UV light was detected. This siderophore was named fluorebactin (70). Secretion of large quantities of SA by WCS374 in SSM is likely to be an artefact, resulting from lack of substrate(s) required for fluorebactin synthesis. Fluorebactin rather than SA may, therefore, be the factor inducing resistance.

Different siderophores thus seem to trigger ISR. Recently, pseudobactin 358 was found to act as an inducer of ISR in Arabidopsis (PAHM Bakker, I Van der Sluis, unpublished observation). How these siderophores trigger ISR in a bacterial strain- and plant species-specific way is unclear at present.

\section{Salicylic Acid}

Experiments with $P$. aeruginosa 7NSK2 as the inducing rhizobacterium and tobacco mosaic virus (TMV) as the challenging leaf pathogen suggest that bacterially produced SA contributes to the induction of systemic resistance by this strain (20). When inoculum of 7NSK2 was grown on an iron-limited 
medium, it reduced the number of spreading lesions caused by Botrytis cinerea on bean by about one half. When inoculum of 7NSK2 was grown on an iron-rich medium it did not suppress the disease (19).

Under iron limitation, 7NSK2 produces three siderophores: pyoverdin, pyochelin and SA. Both pyoverdin-minus mutants and mutants lacking both pyoverdin and pyochelin induced resistance in bean against gray mold and in tobacco against TMV, whereas those deficient in SA production did not. Because SA is a precursor of pyochelin, a role for pyochelin in ISR could not be excluded. Transcriptional activity of SA and pyochelin biosynthetic genes was detected during 7 NSK2 colonization of bean roots, indicating that iron limitation occurs in the rhizosphere. These results demonstrate that induction of systemic resistance in bean by $7 \mathrm{NSK} 2$ is dependent on iron nutritional state, and indicate that specific siderophores function not only in the acquisition of iron by the bacteria, but also in the induction of systemic resistance in the plant. Tobacco plants transformed with the $n a h G$ gene are not induced by 7NSK2 for resistance against TMV (23). Thus, the resistances induced by 7NSK2 in bean and tobacco are both dependent on bacterially produced SA $(19,20)$.

$P$. fluorescens $\mathrm{CHA} 0$, which produces a pyoverdin siderophore and SA in culture (71), induced PRs in tobacco and suppressed necrosis caused by tobacco necrosis virus (TNV) (67). Strain CHA400, a Sid ${ }^{-}$mutant of CHA0, still induced PRs but only partial resistance to TNV, implicating the involvement of the pyoverdin siderophore of CHA0 in the induction of resistance against TNV. The transposon insertion generating the $\mathrm{Sid}^{-}$mutation in CHA400 was not localized, however, so it is not clear whether the loss of pyoverdin is the only mutation in CHA400. Root colonization of the plants with CHA0 or CHA400, as well as leaf infection with TNV, caused up to fivefold increases in SA in the leaves. Although nahG plants were not tested, it appears that SA was involved. These observations suggest that ISR mediated by CHAO and pathogen-induced SAR in tobacco are not only phenotypically but also mechanistically similar, with elevated SA levels correlated with both responses. It is not clear whether the increase in SA in the bacterized plants was the result of induction by the bacteria of SA synthesis in the plant, or whether the plant takes up bacterially produced SA and translocates it to the leaves. Introduction of the SA biosynthetic gene cluster $p c h D C B A$ from $P$. aeruginosa PAO1 (85) under a constitutive promoter into strain $\mathrm{CHA0}$ did not further increase its suppression of TNV or black root rot in tobacco. However, introduction into the non SA-producing strain P3, leading to the production of $0.8 \mu \mathrm{g} \mathrm{SA} .10^{9} \mathrm{cfu}^{-1}$, made this poor biocontrol agent an effective inducer, clearly implicating SA as the inducing determinant of ISR in this system (78).

The SA-producing rhizobacterial strain S. marcescens 90-166 induced resistance to wildfire, caused by $P$. syringae pv. tabaci, in both untransformed and $n a h G$-transformed tobacco. Moreover, mini-Tn5 phoA mutants, which did not 
produce detectable amounts of SA, induced resistance to the same level in both types of plants, as well as ISR of cucumber against anthracnose (75). Thus, bacterial SA does not appear to be involved in disease resistance induced by this strain.

These contrasting results implicate SA production by 7NSK2 in the induction of systemic resistance in bean and tobacco $(19,20)$, but not by $90-166$ in that induced in cucumber and tobacco (75). In radish, induction of systemic resistance by WCS374 and WCS417 was clearly associated with the capacity of these strains to produce SA (54), but involvement of SA in the induction remains to be proved. The latter also holds for the systemic resistance induced in tobacco by CHA0 (67). It is possible that a rhizobacterial strain can induce resistance by different mechanisms, depending on the local conditions in the rhizosphere. For instance, a strain could induce ISR through a constitutive mechanism, while starting to produce SA, and consequently trigger further resistance through SA production when iron-limiting conditions are encountered.

\section{THE INDUCED STATE IN THE PLANT}

\section{Induced Systemic Resistance is Generally Not Associated with Pathogenesis-Related Proteins}

Induction of SAR by SA is associated with the accumulation of PRs $(38,95,97)$. At least eight of the ten major PRs induced in tobacco in response to pathogens causing hypersensitive necrosis, were found in the intercellular washing fluid (IWF) of leaves of plants grown in autoclaved soil in the presence of $P$. fluorescens $\mathrm{CHA} 0$, which is likely to produce $\mathrm{SA}$ in the rhizosphere (67). However, the SA-dependent resistance induced by $P$. aeruginosa 7NSK2 was apparently not associated with changes in protein composition in the protected leaves (G de Meyer, M Höfte, personal communication).

Treatment of radish leaves with avirulent pathogens or millimolar concentrations of SA induced SAR and PR-homologues of the families PR-1, -2 and -5 (34). However, neither root-applied low doses of SA nor rhizobacterial strains triggering ISR induced PRs under either high- or low-iron conditions $(34,35)$. While strong resistance is induced by the rhizobacteria and their $\mathrm{OA}^{-}$-mutants under low-iron conditions, SA is apparently not produced in sufficient quantities to induce PRs. While the pathogen Pst induced high levels of PRs, the rhizobacteria did not, even though the latter induced a level of protection against For at least as high. Thus, PRs do not seem to contribute to the level of resistance attained in radish against Fusarium wilt.

This lack of PR-gene expression in treated radish plants suggests that the mechanism of resistance induction by P. fluorescens WCS374 and WCS417 
is different from SAR. In contrast, the association of PRs with the resistance induced by CHA0 in tobacco against TMV indicates involvement of SAR.

\section{Absence of Consistent Alterations in Metabolism of Phytoalexins or Inhibitors}

The enhanced defensive capacity of plants exhibiting ISR might rely on the presence of enhanced levels of compounds that inhibit plant pathogens such as phytoalexins. Resistance of carnation to Fusarium wilt is polygenic and associated with the accumulation of phytoalexins (3). No increase in phytoalexin levels was detectable in carnation following inoculation by WCS417 and prior to challenge; upon subsequent inoculation with Fod, however, phytoalexin levels were greater in plants inoculated with WCS417 than in non-bacterized plants (98). The polygenic resistance of radish to Fusarium wilt (36), in contrast, does not appear to be associated with phytoalexins. Despite various attempts, we have been unable to link ISR to alterations in inhibitory compounds, electrophoretic protein patterns, or enzyme activities in radish. Nevertheless, upon challenge inoculation, the resistance response of radish is accelerated and enhanced.

Bacterial LPS acts as the major determinant of ISR in radish (56). In tobacco, LPS from the pathogen P. solanacearum induces the synthesis of PR-like polypeptides (53), and LPS preparations from $P$. syringae pv. syringae act as weak, non-specific elicitors of phytoalexin biosynthesis in soybean hypocotyls (6). Purified LPS from Xanthomonas campestris pv. campestris induced accumulation of $\beta$-1,3-glucanase mRNA in turnip at concentrations as low as $1 \mu \mathrm{g} \cdot \mathrm{ml}^{-1}$. In this case, the lipid A-inner core was required for activity but the OA had no role (72). This contrasts with the induction of resistance by the WCS strains, which depends on the OA and is not associated with the induction of phytoalexins or PRs prior to challenge inoculation. Nevertheless, LPS evidently triggers the defense-related ISR signaling pathway.

Involvement of ISR in the protection of bean by P. fluorescens S97 is plausible on the basis of host plant alterations (2). Reduced levels of the challenging pathogen in protected leaves and in the IWF from those leaves were correlated with a general rise in protein content in the IWF and associated with accumulation of certain phenolic compounds. Hence, changes in plant metabolism occurred as a result of prior seed bacterization, but a causal relationship with disease suppression was not established.

Indications for the induction of plant defense responses were also obtained upon root colonization by other fluorescent Pseudomonas spp. A P. aureofaciens strain induced symptoms of a hypersensitive response on bean cotyledons and in bean suspension cultures, and induced defense proteins resembling the plant's response to pathogens inducing SAR (109). Isolates of $P$. tolaasii and 
P. putida induced only certain acid-soluble proteins. Upon inoculation on cotyledons, some accumulation of phytoalexins and phenolics was associated with a slight browning reaction, indicating that the bean plants responded defensively to foliar application of these rhizobacterial species. Upon root treatment, however, no metabolic changes were apparent, suggesting that the rhizobacteria had only very minor effects on root metabolism. These observations are important in showing that at least some rhizobacterial species have limited pathogenic activity when applied to leaves, and initiate defense reactions also observed in leaves exhibiting SAR. Unfortunately, no attempt was made to relate these metabolic effects to disease suppression.

Suppressive activity of three different types of compost on root rot, caused by P. ultimum and $P$. aphanidermatum, and anthracnose, caused by $C$. orbiculare, was associated with enhanced leaf peroxidase activity in cucumber (112). Rhizobacteria stimulated by the substrates present in composts are thought to be involved in this induced resistance, but their contribution has not been verified. Inoculation with $C$. orbiculare dramatically increased the activity of the major peroxidase isoenzyme in plants grown in disease-conducive peat mix, but this increase was even greater in plants grown in suppressive compost-amended mixes.

PGPR strains $P$. putida 89B-27 and S. marcescens 90-166 induce resistance of cucumber against cucumber mosaic virus (CMV), exhibited as a reduced number of plants with symptoms. Protected plants did not develop mosaic symptoms throughout the experimental period, whereas pathogen-induced SAR is expressed as a delay in symptom development (10). No viral antigen was detected by enzyme-linked immunosorbent assay in any asymptomatic PGPRtreated plants (77), indicating that the plants inoculated with inducing bacteria had become refractory to viral infection. Oligosaccharide elicitors of fungal origin have been reported to prevent infection of tobacco by TMV (46), and it is possible that the protection seen in PGPR-treated cucumber against CMV was due to a bacterially derived oligosaccharide moiety that acts directly or indirectly in preventing virus entry into the leaf.

Together, these disparate observations are suggestive of metabolic alterations in the plant being associated with ISR, but their significance remains to be determined.

\section{Structural Alterations}

In radish, ISR against Fusarium wilt was expressed primarily as a reduction in the percentage of diseased plants, apparently resulting from a more frequent failure of the causal pathogen For to reach or colonize the vascular tissue (34). Such impediment to fungal ingress might involve cellular alterations in the epidermal and cortical cells that inhibit further colonization. 
Evidence for such PGPR-induced structural modifications was described recently for pea root tissue (9). Agrobacterium rhizogenes Ri T-DNA-transformed pea roots preinoculated with the endophytic biocontrol strain Bacillus pumilus SE34 were protected against the root-rot fungus F. oxysporum f.sp. pisi (Fop). Although the bacterium and the fungus were in contact, fungal hyphae interacting with cells of the bacterium at the root surface maintained active growth and penetrated the root epidermis. Therefore, the protective mechanism did not appear to rely on a direct antagonism in the rhizosphere. In nonbacterized roots, the pathogen multiplied abundantly through much of the tissue including the vascular stele. Root bacterization by itself did not lead to morphological alterations of root tissue. Upon challenge inoculation, however, pathogen growth was restricted to the epidermis and the outer cortex. The walls of these cells were strengthened at sites of attempted fungal penetration by appositions containing large amounts of callose and phenolic materials, effectively preventing fungal ingress. Phenolic materials were also seen in intercellular spaces as well as at the surface or inside the invading hyphae of the pathogen. Thus, the protection afforded by SE34 involved host cell wall rigidification upon challenge inoculation with Fop (9). Similar wall appositions and papillae were seen in pea roots treated with the rhizobacterium $P$. fluorescens strain 63-28R upon challenge inoculation with either Fop or Pythium ultimum $(7,8)$, indicating a general induction of defensive physical barriers to pathogen ingress. P. fluorescens WCS417 also has been reported to induce a thickening of cortical cell walls in tomato roots if epidermal or hypodermal cells were colonized densely by the bacterium (27).

\section{A Novel Signaling Pathway for Induced Systemic Resistance in Arabidopsis}

In recent years, the advantages of using Arabidopsis thaliana as a model for studying the molecular genetics of pathogen-induced SAR have become clear through the identification of mutants blocked at specific signaling steps (21). A similar approach was taken to study rhizobacteria-mediated ISR and compare it to SAR. To this end, the bioassay for studying ISR in radish was adapted to Arabidopsis in order to study induction of systemic resistance against root pathogens (73). To study ISR against foliar pathogens, seedlings were transplanted into autoclaved potting soil into which rhizobacterial strains were mixed. In all experiments, colonization by the rhizobacteria remained confined to the treated plant parts, i.e. distal root parts in the separate-inoculation rock wool bioassay and roots in a potting soil bioassay.

Because radish and Arabidopsis are both crucifers, it was expected that they would react similarly to the rhizobacterial strains. Of the three rhizobacterial strains tested previously on radish, only strain WCS417 induced resistance 
in both radish and Arabidopsis. Strain WCS374, effective on radish, did not trigger ISR in Arabidopsis, whereas strain WCS358, which did not induce resistance on radish, was almost as effective as WCS417 in triggering ISR in Arabidopsis (100). Hence, these three strains showed different specificities in the induction of resistance on radish and on Arabidopsis. WCS374 colonized roots of Arabidopsis to slightly lower levels than the other strains, but still reached numbers well above $10^{5} \mathrm{cfu} . \mathrm{g}^{-1}$ root, the threshold population needed to elicit ISR in radish (76). Both WCS374 and WCS417 possess several resistanceinducing determinants (Table 2), which may or may not be perceived by different plant species. The LPS of WCS417 is the main determinant in radish and carnation $(56,99)$, and LPS-containing bacterial cell walls also trigger ISR in Arabidopsis (100). However, WCS417 and its $\mathrm{OA}^{-}$mutant induce resistance in Arabidopsis to similar levels. This indicates that WCS417 produces more than a single factor that leads to ISR in Arabidopsis.

When resistance was induced, it was expressed against both Fusarium wilt and bacterial speck. Arabidopsis developed chlorosis and wilting after infection with For and necrotic lesions surrounded by extensive spreading chlorosis upon inoculation with $P$. syringae pv. tomato (100). In addition, growth of $P$. syringae pv. tomato in the infected leaves was strongly inhibited $(73,100)$. In culture medium containing high levels of iron, the rhizobacteria WCS417 and WCS358 did not inhibit the pathogens For and $P$. syringae pv. tomato (100), so disease suppression could not be attributed to production and transport of antibiotics. The level of resistance attained by application of either WCS417 or WCS358 was similar to that of SAR induced by virulent or avirulent isolates of $P$. syringae pv. tomato or the chemical inducers SA or 2,6-dichloroisonicotinic acid (INA) against the virulent isolate of $P$. syringae pv. tomato. ISR also proved effective against the fungal leaf pathogen Peronospora parasitica, although it was less effective than chemically induced SAR (J Ton, CMJ Pieterse, unpublished observations). Thus, severity of disease induced by either bacteria or fungi and proliferation of the pathogens was reduced, indicating the activation of a general defensive mechanism (100).

Plants inoculated with the pathogen $P$. syringae pv. tomato, or sprayed with SA or INA developed SAR and accumulated PR-1, -2 and -5 mRNAs (73). Plants inoculated with WCS417 or WCS358 developed ISR, but PRgene expression or accumulation of PRs was not detected (100). Therefore, in Arabidopsis, as in radish, the induction of ISR was not coupled to the activation of PR genes. In $n a h G$ plants, WCS417 and WCS358 were as effective in inducing ISR against bacterial speck as in untransformed plants, demonstrating that these rhizobacteria activate a signaling pathway different from the one that controls SAR (73). Strikingly, the strain capable of producing the largest amount of SA in vitro, WCS374, did not induce resistance in Arabidopsis, 
whereas the one incapable of producing SA, WCS358, did induce resistance (100). The latter result demonstrates that bacterially produced SA did not play a role in triggering ISR. Moreover, the finding that WCS358 was equally capable of inducing systemic resistance in untransformed and in $n a h G$ transformed Arabidopsis demonstrates that plant-derived SA was also not involved. Thus, SA is not required for the triggering of ISR by these strains.

Arabidopsis mutant nprl does not express PR-genes and does not exhibit SAR (15). Because rhizobacteria-mediated ISR was found to be independent of SA and not associated with PRs, it was expected that ISR would still be expressed in this mutant. However, the nprl mutant of Arabidopsis did not express WCS417-mediated ISR (74). This finding implies that NPR1 functions beyond the expression of PR-genes and is required for both pathogen-dependent and rhizobacteria-mediated systemic induced resistance. The $n p r l$ gene is allelic to niml (no immunity) (22) and sai (SA-insensitive) (86) and encodes an ankyrin repeat-containing protein with homology to the mammalian signal transduction factor $\mathrm{I} \kappa \mathrm{B} \alpha$, which has been implicated in disease resistance responses in a wide range of higher organisms $(16,81 \mathrm{a})$. NPR1 is thought to be a regulatory protein that functions in the terminal part of the signaling pathway of SAR. The nonresponsiveness of the Arabidopsis nprl mutant to rhizobacteria demonstrates that SAR and ISR converge at the last part of the signaling pathway. This can explain why SAR and ISR are phenotypically similar in that in both the defensive capacity of the plant against a broad spectrum of pathogens is enhanced. Yet, PRs are induced concomitant with SAR, whereas activation of PR genes is not part of the pathway leading to ISR in Arabidopsis. Apparently, NPR1 regulates defense responses mediated by different signaling pathways (Figure 1).

Ethylene is an important signaling compound of plant defense responses (12). Although it is not required for the development of SAR (51), it enhances the sensitivity of Arabidopsis to SA (52). Moreover, using tobacco transformed with a mutant etrl gene from Arabidopsis, which confers dominant insensitivity to ethylene (17), it was established recently that ethylene perception is required for a high level of SAR in tobacco against TMV (45). To investigate the role of ethylene in the expression of ISR, the ethylene-insensitive Arabidopsis mutant etr 1 (17) was tested (74). WCS417 was not capable of inducing resistance against bacterial speck in this mutant, whereas pathogen-induced SAR developed in the mutant. Because WCS417 colonized roots of the etrl mutant and wild-type to the same extent, these observations implicate ethylene perception as a specific and essential step in the signal-transduction pathway leading to ISR. Indeed, application of the ethylene precursor, 1-aminocyclopropane-1-carboxylic acid (ACC), to wild-type plants induced resistance against $P$. syringae pv. tomato to the same level as the rhizobacterial strains, not only in the wild-type but also in Arabidopsis transformed with nahG (74). These observations suggest 


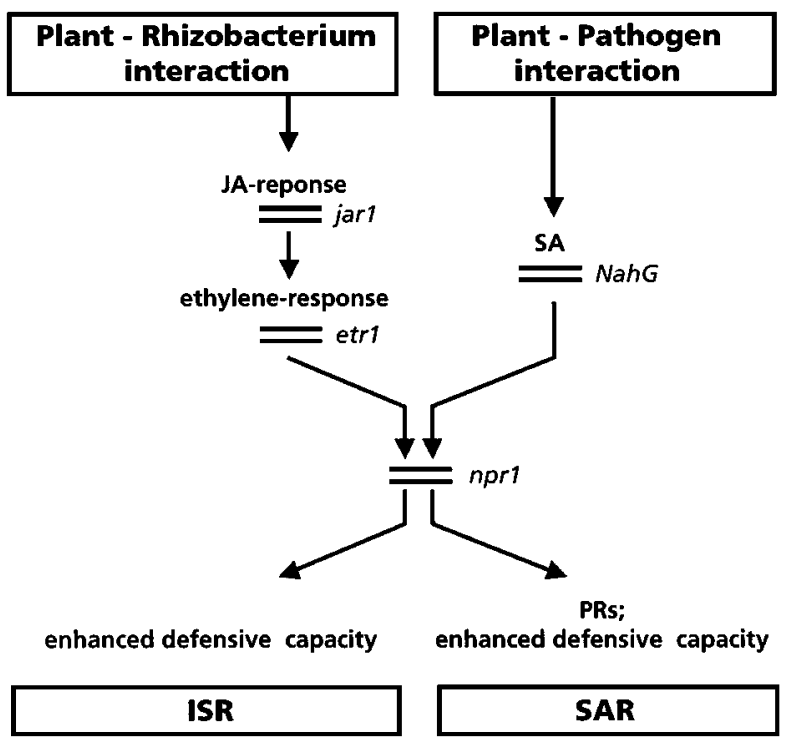

Figure 1 Signal-transduction pathways leading to pathogen-induced systemic acquired resistance (SAR) and rhizobacteria-mediated induced systemic resistance (ISR) in Arabidopsis thaliana. In plant species other than Arabidopsis, rhizobacterially-produced salicylic acid can trigger the SAR pathway as well as ISR.

that inducing bacteria trigger ethylene production or modulate perception of ethylene by the plant.

JA has also been implicated as a signal in several defensive responses (103). The Arabidopsis JA response mutant jarl (87) exhibits wild-type levels of pathogen-induced SAR but fails to express rhizobacteria-mediated ISR (74). On wild-type plants, application of methyl jasmonate (MeJA) induced resistance, as did ACC. However, MeJA did not induce resistance in the etrl mutant, whereas ACC did induce resistance in the jarl mutant, indicating that perception of JA is required prior to ethylene signaling. Neither MeJA, nor ACC induced resistance in the nprl mutant, confirming their action prior to NPR1 (74). How perception of JA and ethylene are coupled to ISR is still unclear. The hormones might be required without an increase in their endogenous levels. For instance, ethylene acts as the endogenous regulator of senescence in rice leaves, and application of JA promotes senescence upon detachment (92). In MeJA-treated rice leaf segments ethylene production was even lower than in water-treated leaves. JA-promoted senescence therefore appears to be due to an increase in ethylene sensitivity. 
In the assays used, treatment of Arabidopsis seedlings with inducing rhizobacteria occurred a few days to a few weeks before challenge inoculation, and spatial separation between the rhizobacteria and the challenging pathogen was verified. Moreover, ISR in Arabidopsis was effective against different pathogens. However, whereas ecotypes Columbia and Landsberg-erecta were responsive to induction by WCS417 or WCS358, ecotype RLD was not induced (100). The latter ecotype possessed a lower level of basal resistance to $P$. syringae pv. tomato (90), supporting the notion that induced resistance represents an enhancement of the extant defensive capacity. The lack of expression of ISR in ecotype RLD, as well as in the jarl, etrl and nprl mutants, rules out the possibility that rhizobacteria-produced antibiotics might have been responsible for, or contributed to, ISR. Thus, ISR in Arabidopsis truly meets several of the criteria for systemic induced resistance.

By requiring JA and ethylene signaling, but not SA, the signaling pathway triggered by these resistance-inducing rhizobacteria in Arabidopsis is different from SAR (Figure 1). To distinguish the resistances induced through the two different pathways, and in line with the common usage of the term "SAR" to describe induced resistance dependent on SA signaling and associated with the induction of PR genes, it appears best to refer to SAR when these conditions are met (96). It has been proposed to restrict the term "ISR" to denote the systemic resistance induced by rhizobacteria that is not dependent on SA signaling and not associated with accumulation of PRs $(73,96)$. Using these definitions, rhizobacteria producing SA and inducing PRs in the plant can be considered to trigger the SAR pathway rather than the ISR pathway (Table 2).

Although the level of resistance attained by SAR and ISR is generally similar in Arabidopsis, ISR usually affords slightly lesser protection than SAR $(73,100)$. Preliminary findings suggest that resistance induced by PGPR can be further boosted by application of SA, suggesting that bacteria do not activate the same spectrum of plant responses as pathogens do. Indeed, combination of SAR and ISR can afford a higher level of protection than each one separately (SCM Van Wees, CMJ Pieterse, unpublished observations). SAR is associated with the accumulation of PRs, but these are lacking in ISR. Hence, ISR must depend on a different induced state, markers for which have not yet been identified.

\section{PERSPECTIVES OF INDUCED SYSTEMIC RESISTANCE FOR DISEASE SUPPRESSION UNDER FIELD CONDITIONS}

Because resistance-inducing PGPR are naturally occurring rhizosphere soil inhabitants, the question can be asked whether plants grown under field conditions 
are likely to be induced already (93). No studies specifically addressing this point appear to have been conducted. However, PGPR can protect plants from disease under commercial cropping conditions and, in certain cases, disease suppression is attributed to induced resistance. In four consecutive years, seed treatment with the resistance-inducing $P$. fluorescens strain WCS374 reduced fusarium wilt of radish in a naturally infested greenhouse by up to $50 \%$ (57). In bioassays using the same soil, the $\mathrm{OA}^{-}$-mutant did not suppress disease (56). Since the OA of the LPS induces ISR but is not toxic to the causal pathogen For, this observation is highly suggestive of ISR being a mechanism responsible for disease suppression.

Four PGPR strains applied as seed treatments followed by a soil drench at transplanting (106) suppressed angular leaf spot and anthracnose of cucumber in three field trials over a two-year period. In all three trials, most PGPR strains promoted early season plant growth and enhanced yield. Under similar conditions, naturally occurring bacterial wilt, caused by E. tracheiphila, was also significantly reduced (43). These observations indicate that treatments with resistance-inducing rhizobacteria can both promote growth and reduce disease incidence under field conditions.

Induction of resistance is dependent on colonization of the root system by the inducing rhizobacteria in sufficient numbers to trigger SAR or ISR. This is usually accomplished by adding bacterial suspensions to the soil before sowing or at transplanting, or by coating seeds with high numbers of bacteria (39). These treatments are designed to give the protective bacteria a competitive advantage over the indigenous soil microflora. PGPR depend on the association with plant roots for survival. A minimal concentration of $10^{5} \mathrm{cfu} . \mathrm{g}^{-1}$ root appears to be required for induction of systemic resistance in, for example, radish (76). Although total bacterial populations in the rhizosphere can exceed such levels by far, bacterial diversity is enormous and any inducing strain that may be present naturally is unlikely to exceed this threshold.

Some root-colonizing bacteria may enter plant roots and live as endophytes inside the plant $(41,91)$. It may be speculated that endophytic behavior aids in the induction of resistance, because more plant cells are being contacted by the bacteria than by isolates confined to the rhizosphere $(9,27)$. Although P. fluorescens $\mathrm{WCS} 417$ behaves as an endophyte on tomato, its $\mathrm{OA}^{-}$-mutant colonized internal root tissues less frequently. However, unlike biological control mediated through bacterial antagonism, sustained disease suppression can be effective even if populations of inducing bacteria decline over time. Once activated, the natural resistance mechanisms of the host maintain an enhanced defensive capacity for prolonged periods and are effective against multiple pathogens. Induced resistance can even be transmitted to regenerants from tissue cultures of induced plants (94). Inconsistencies encountered in the induction of resistance 
in carnation may be linked to vegetative propagation of this plant, because cuttings used as non-inoculated controls could be taken from root stocks that were inadvertently induced (E Hoffland, SCM Van Wees, unpublished observations).

To reduce the dependence on chemical crop protectants for disease control in agriculture, biological agents are receiving increasing attention. Benzothiadiazole, a chemical inducer of SAR (30), is currently being commercialized as an activator of natural plant defenses. Resistance-inducing rhizobacteria offer an attractive alternative in providing a natural, safe, effective, persistent and durable type of protection. Protection based on biological agents is not always reliable and is seldom as effective as chemical treatments. However, different treatments may be combined, and combinations of biocontrol agents that suppress diseases by complementary mechanisms may further reduce disease losses. Combination of chemically induced SAR in tobacco seedlings with application of the biocontrol strain Bacillus cereus UW85 resulted in additive suppression of disease caused by Pythium torulosum, P. aphanidermatum or Phytophthora parasitica (18). Rhizobacteria-mediated ISR will likewise be a valuable addition to the options available for environmentally friendly plant disease control.

\section{ACKNOWLEDGMENT}

We thank J Van den Heuvel for critically reading the manuscript.

Visit the Annual Reviews home page at http://www.AnnualReviews.org.

Literature Cited

1. Alström S. 1991. Induction of disease resistance in common bean susceptible to halo blight bacterial pathogen after seed bacterization with rhizosphere pseudomonads. J. Gen. Appl. Microbiol. 37: 495-501

2. Alström S. 1995. Evidence of disease resistance induced by rhizosphere pseudomonad against Pseudomonas syringae pv. phaseolicola.J. Gen. Appl. Microbiol. 41:315-25

3. Baayen RP, Niemann GJ. 1989. Correlations between accumulation of dianthramides, dianthalexin and unknown compounds, and partial resistance to Fusarium oxysporum f.sp. dianthi in eleven carnation cultivars. J. Phytopathol. 126:281-92

4. Bakker PAHM, Raaijmakers JM, Schippers B. 1993. Role of iron in the sup- pression of bacterial plant pathogens by fluorescent pseudomonads. In Biological Control of Soil-Borne Plant Pathogens ed. D Hornby, RJ Cook, Y Henis, WH Ko, AD Rovira, et al, pp. 131-42. Wallingford: CAB Int.

5. Bakker PAHM, Van Peer R, Schippers B. 1991. Suppression of soil-borne plant pathogens by fluorescent pseudomonads: mechanisms and prospects. In Biotic Interactions and Soil-Borne Diseases, ed. ABR Beemster, GJ Bollen, M Gerlagh, MA Ruissen, B Schippers, et al, pp. 21730. Amsterdam: Elsevier

6. Barton-Willis PA, Wang MC, Holliday MJ, Long MR, Keen NT. 1984. Purification and composition of lipopolysaccharides from Pseudomonas syringae pv. glycinea. Physiol. Plant Pathol. 25:38798 
7. Benhamou N, Bélanger RR, Paulitz TC. 1996. Induction of differential host responses by Pseudomonas fluorescens in $R i$ T-DNA-transformed pea roots after challenge with Fusarium oxysporum f.sp. pisi and Pythium ultimum. Phytopathology $86: 1174-85$

8. Benhamou $\mathrm{N}$, Bélanger RR, Paulitz TC. 1996. Pre-inoculation of $R i$ TDNA-transformed pea roots with Pseudomonas fluorescens inhibits colonization by Pythium ultimum Trow: an ultrastructural study. Planta 199:105-17

9. Benhamou N, Kloepper JW, QuadtHallman A, Tuzun S. 1996. Induction of defense-related ultrastructural modifications in pea root tissues inoculated with endophytic bacteria. Plant Physiol. 112:919-29

10. Bergstrom GC, Johnson MC, Kuc J. 1982. Effects of local infection of cucumber by Colletotrichum lagenarium, Pseudomonas lachrymans, or tobacco necrosis virus on systemic resistance to cucumber mosaic virus. Phytopathology 72:92226

11. Bigirimana J, De Meyer G, Poppe J, Elad Y, Höfte M. 1997. Induction of systemic resistance on bean (Phaseolus vulgaris) by Trichoderma harzianum. Med. Fac. Landbouwwet. Gent. In press

12. Boller T. 1991. Ethylene in pathogenesis and disease resistance. In The Plant Hormone Ethylene, ed. AK Mattoo, JC Suttle, pp. 293-314. Boca Raton: CRC Press

13. Bozarth RF, Ross AF. 1964. Systemic resistance induced by localized virus infections: extent of changes in uninfected plant parts. Virology 24:446-55

14. Cameron RK, Dixon R, Lamb C. 1994. Biologically induced systemic acquired resistance in Arabidopsis thaliana. Plant J. 5:715-25

15. Cao H, Bowling SA, Gordon AS, Dong X. 1994. Characterization of an Arabidopsis mutant that is nonresponsive to inducers of systemic acquired resistance. Plant Cell 6:1583-92

16. Cao H, Glazebrook J, Clarke JD, Volko S, Dong X. 1997. The Arabidopsis NPR1 gene that controls systemic acquired resistance encodes a novel protein containing ankyrin repeats. Cell 88:57-63

17. Chang C, Kwok SF, Bleecker AB, Meyerowitz EM. 1993. Arabidopsis ethylene-response gene ETRI: similarity of product to two-component regulators. Science 262:539-44

18. Chen J, Jacobson LM, Handelsman J, Goodman RM. 1996. Compatibility of systemic acquired resistance and micro- bial biocontrol for suppression of plant disease in a laboratory assay. Mol. Ecol. 5:73-80

19. De Meyer G, Höfte M. 1997. Salicylic acid produced by the rhizobacterium Pseudomonas aeruginosa 7NSK2 induces resistance to leaf infection by Botrytis cinerea on bean. Phytopathology 87:588-93

20. De Meyer G, Höfte M. 1997. Induction of systemic resistance by the rhizobacterium Pseudomonas aeruginosa 7NSK2 is a salicylic acid dependent phenomenon in tobacco. Proc. IOBC/EFPP Workshop: Mol. Approaches Biol. Control, 5th, Delémont. In press

21. Delaney TP. 1997. Genetic dissection of acquired resistance to disease. Plant Physiol. 113:5-12

22. Delaney TP, Friedrich L, Ryals JA. 1995. Arabidopsis signal transduction mutant defective in chemically and biologically induced disease resistance. Proc. Natl. Acad. Sci. USA 92:6602-6

23. Delaney TP, Uknes S, Vernooij B, Friedrich L, Weymann K, et al. 1994. A central role of salicylic acid in plant disease resistance. Science 266:1247-50

24. Duijff BJ, Alabouvette C, Lemanceau P. 1996. Involvement of induced systemic resistance in the control of fusarium wilt of tomato by Fusarium oxysporum strain FO47 and Pseudomonas fluorescens strain WCS417r. IOBC wprs Bull. 19:120-24

25. Duijff BJ, Bakker PAHM, Schippers B. 1994. Suppression of fusarium wilt of carnation by Pseudomonas putida WCS358 at different levels of disease incidence and iron availability. Biocontrol Sci. Technol. 4:279-88

26. Duijff BJ, Bakker PAHM, Schippers B. 1994. Ferric pseudobactin 358 as an iron source for carnation. J. Plant Nutr. 17:2069-78

27. Duijff BJ, Gianinazzi-Pearson V, Lemanceau P. 1997. Involvement of the outer membrane lipopolysaccharides in the endophytic colonization of tomato roots by biocontrol Pseudomonas fluorescens strain WCS417r. New Phytol. 135:32534

28. Duijff BJ, Meijer JW, Bakker PAHM, Schippers B. 1993. Siderophore-mediated competition for iron and induced resistance in the suppression of fusarium wilt of carnation by fluorescent Pseudomonas spp. Neth. J. Plant Pathol. 99:277-89

29. Gaffney T, Friedrich L, Vernooij B, Negrotto D, Nye G, et al. 1993. Requirement of salicylic acid for the induction 
of systemic acquired resistance. Science 261:754-56

30. Görlach J, Volrath S, Knauf-Beiter G, Hengy G, Beckhove U, et al. 1996. Benzothiadiazole, a novel class of inducers of systemic acquired resistance, activates gene expression and disease resistance in wheat. Plant Cell 8:629-43

31. Graham LT, Sequeira L, Huang TSR. 1977. Bacterial lipopolysaccharides as inducers of disease resistance in tobacco. Appl. Environ. Microbiol. 34:424-32

32. Ham KS, Kauffmann S, Albersheim P, Darvill AG. 1991. Host-pathogen interactions XXXIX. A soybean pathogenesisrelated protein with $\beta$-1,3-glucanase activity releases phytoalexin elicitor-active heat-stable fragments from fungal walls. Mol. Plant-Microbe Interact. 4:545-52

33. Hammerschmidt R, Kuc J. 1995. Induced Resistance to Disease in Plants. Dordrecht: Kluwer. $182 \mathrm{pp}$.

34. Hoffland E, Pieterse CMJ, Bik L, Van Pelt JA. 1995. Induced systemic resistance in radish is not associated with accumulation of pathogenesis-related proteins. Physiol. Mol. Plant Pathol. 46:309-20

35. Hoffland E, Hakulinen J, Van Pelt JA. 1996. Comparison of systemic resistance induced by avirulent and non-pathogenic Pseudomonas species. Phytopathology 86:757-62

36. Hoffland E, Niemann GJ, Van Pelt JA, Pureveen JBM, Eijkel GB, et al. 1996. Relative growth rate correlates negatively with pathogen resistance in radish: the role of plant chemistry. Plant Cell Environ. 19:1281-90

37. Hyakumachi M. 1997. Induced systemic resistance against anthracnose in cucumber due to plant growth-promoting fungi and studies on mechanisms. See Ref. 72a, pp. 164-69

38. Kessmann H, Staub T, Ligon J, Oostendorp M, Ryals J. 1994. Activation of systemic acquired disease resistance in plants. Eur. J. Plant Pathol. 100:359-69

39. Kloepper JW. 1996. Host specificity in microbe-microbe interactions. Bioscience 46:406-9

40. Kloepper JW, Leong J, Teintze M, Schroth MN. 1980. Enhanced plant growth by siderophores produced by plant growth-promoting rhizobacteria. Nature 286:885-86

41. Kloepper JW, Schippers B, Bakker PAHM. 1992. Proposed elimination of the term endorhizosphere. Phytopathology 82:726-27

42. Kloepper JW, Tuzun S, Kuc JA. 1992. Proposed definitions related to induced disease resistance. Biocontrol Sci. Technol. 2:349-51

43. Kloepper JW, Tuzun S, Liu L, Wei G. 1993. Plant growth-promoting rhizobacteria as inducers of systemic disease resistance. In Pest Management: Biologically Based Technologies, ed. RD Lumsden, JL Vaughn, pp. 156-65. Washington, DC: Am. Chem. Soc.

44. Kluepfel DA. 1993. The behavior and tracking of bacteria in the rhizosphere. Annu. Rev. Phytopathol. 31:441-72

45. Knoester M. 1998. The involvement of ethylene in plant disease resistance. $\mathrm{PhD}$ thesis, Utrecht Univ.

46. Kopp M, Rouster J, Fritig B, Darvill A, Albersheim P. 1989. Host-pathogen interactions XXXII. A fungal glucan preparation protects Nicotianae against infection by viruses. Plant Physiol. 90:208-16

47. Kuc J. 1982. Induced immunity to plant disease. Bioscience 32:854-60

48. Kuc J. 1995. Induced systemic resistance-an overview. See Ref. 33, pp. 16975

49. Kuc J, Richmond S. 1977. Aspects of the protection of cucumber against Colletotrichum lagenarium by Colletotrichum lagenarium. Phytopathology 67:533-36

50. Lamb TG, Tonkyn DW, Kluepfel DA. 1996. Movement of Pseudomonas aureofaciens from the rhizosphere to aerial plant tissue. Can. J. Microbiol. 42:111220

51. Lawton KA, Potter SL, Uknes S, Ryals J. 1994. Acquired resistance signal transduction in Arabidopsis is ethylene independent. Plant Cell 6:581-88

52. Lawton K, Weymann K, Friedrich L, Vernooij B, Uknes S, et al. 1995. Systemic acquired resistance in Arabidopsis requires salicylic acid but not ethylene. Mol. PlantMicrobe Interact. 8:863-70

53. Leach JE, Sherwood J, Fulton RW, Sequeira L. 1983. Comparison of soluble proteins associated with disease resistance induced by bacterial lipopolysaccharide and by viral necrosis. Physiol. Plant Pathol. 23:377-85

54. Leeman M, Den Ouden FM, Van Pelt JA, Dirkx FPM, Steijl H, et al. 1996. Iron availability affects induction of systemic resistance to fusarium wilt of radish by Pseudomonas fluorescens. Phytopathology 86:149-55

55. Leeman M, Van Pelt JA, Den Ouden FM, Heinsbroek M, Bakker PAHM, et al. 1995. Induction of systemic resistance by Pseudomonas fluorescens in radish cultivars differing in susceptibility to 
fusarium wilt, using a novel bioassay. Eur. J. Plant Pathol. 101:655-64

56. Leeman M, Van Pelt JA, Den Ouden FM, Heinsbroek M, Bakker PAHM, et al. 1995. Induction of systemic resistance against fusarium wilt of radish by lipopolysaccharides of Pseudomonas $\mathrm{flu}$ orescens. Phytopathology 85:1021-27

57. Leeman M, Van Pelt JA, Hendrickx MJ, Scheffer RJ, Bakker PAHM, et al. 1995. Biocontrol of fusarium wilt of radish in commercial greenhouse trials by seed treatment with Pseudomonas fluorescens WCS374. Phytopathology 85:1301-5

58. Lemanceau P, Bakker PAHM, De Kogel WJ, Alabouvette C, Schippers B. 1992. Effect of pseudobactin 358 production by Pseudomonas putida WCS358 on suppression of fusarium wilt of carnations by nonpathogenic Fusarium oxysporum Fo47. Appl. Environ. Microbiol. 58:297882

59. Lemanceau P, Bakker PAHM, De Kogel WJ, Alabouvette C, Schippers B. 1993. Antagonistic effect of nonpathogenic Fusarium oxysporum Fo47 and pseudobactin 358 upon pathogenic Fusarium oxysporum f.sp. dianthi. Appl. Environ. Microbiol. 59:74-82

60. Linthorst HJM. 1991. Pathogenesisrelated proteins of plants. Crit. Rev. Plant Sci. 10:123-50

61. Liu L, Kloepper JW, Tuzun S. 1995. Induction of systemic resistance in cucumber against fusarium wilt by plant growthpromoting rhizobacteria. Phytopathology 85:695-98

62. Liu L, Kloepper JW, Tuzun S. 1995. Induction of systemic resistance in cucumber against angular leaf spot by plant growth-promoting rhizobacteria. Phytopathology 85:843-47

63. Liu L, Kloepper JW, Tuzun S. 1995. Induction of systemic resistance in cucumber by plant growth-promoting rhizobacteria: duration of protection and effect of host resistance on protection and root colonization. Phytopathology 85:1064-68

64. Loper JE, Buyer JS. 1991. Siderophores in microbial interactions on plant surfaces. Mol. Plant-Microbe Interact. 4:513

65. Lynch JM. 1976. Products of soil microorganisms in relation to plant growth. Crit. Rev. Microbiol. 5:67-107

66. Lynch JM, Whipps JM. 1991. Substrate flow in the rhizosphere. In The Rhizosphere and Plant Growth, ed. DL Keister, PB Cregan, pp. 15-24. Dordrecht: Kluwer

67. Maurhofer M, Hase C, Meuwly P,
Métraux JP, Défago G. 1994. Induction of systemic resistance of tobacco to tobacco necrosis virus by the root-colonizing Pseudomonas fluorescens strain CHA0: influence of the gacA gene and of pyoverdine production. Phytopathology 84:13946

68. Maurhofer M, Keel C, Haas D, Défago G. 1995. Influence of plant species on disease suppression by Pseudomonas fluorescens strain CHA0 with enhanced antibiotic production. Plant Pathol. 44:4050

69. Mazzucchi U, Bazzi C, Pupillo P. 1979. The inhibition of susceptible and hypersensitive reactions by protein-lipopolysaccharide complexes from phytopathogenic pseudomonads: relationship to polysaccharide antigenic determinants. Physiol. Plant Pathol. 14:I19-30

70. Mercado-Blanco J, Olsson PE, Van der Drift KMGM, Thomas-Oates JE, Van Loon LC, et al. 1997. Analysis of a gene cluster involved in the production of salicylic acid and a new siderophore in Pseudomonas fluorescens WCS374. See Ref. 72a, pp. 355-57

71. Meyer JM, Azelvandre P, Georges C. 1992. Iron metabolism in Pseudomonas: salicylic acid, a siderophore of Pseudomonas fluorescens CHA0. BioFactors 4:23-27

72. Newman MA, Daniels MJ, Dow JM. 1995. Lipopolysaccharide from Xanthomonas campestris induces defenserelated gene expression in Brassica campestris. Mol. Plant-Microbe Interact. 8:778-80

72a. Ogoshi A, Kobayashi K, Homma Y, Kodama F, Kondo N, et al, eds. 1997. Plant Growth-Promoting Rhizobacteria-Present Status and Future Prospects. Sapporo: Fac. Agric., Hokkaido Univ.

73. Pieterse CMJ, Van Wees SCM, Hoffland E, Van Pelt JA, Van Loon LC. 1996. Systemic resistance in Arabidopsis induced by biocontrol bacteria is independent of salicylic acid accumulation and pathogenesis-related gene expression. Plant Cell 8:1225-37

74. Pieterse CMJ, Van Wees SCM, Van Pelt JA, Knoester M, Laan R, et al. 1998. A novel signaling pathway controlling induced disease resistance in plants.

75. Press CM, Wilson M, Tuzun S, Kloepper JW. 1997. Salicylic acid produced by Serratia marcescens $90-166$ is not the primary determinant of induced systemic resistance in cucumber or tobacco. Mol. Plant-Microbe Interact. 10:761-68 
76. Raaijmakers JM, Leeman M, Van Oorschot MMP, Van der Sluis I, Schippers B, et al. 1995. Dose-response relationships in biological control of fusarium wilt of radish by Pseudomonas spp. Phytopathology 85:1075-81

77. Raupach GS, Liu L, Murphy JF, Tuzun S, Kloepper JW. 1996. Induced systemic resistance in cucumber and tomato against cucumber mosaic cucumovirus using plant growth-promoting rhizobacteria (PGPR). Plant Dis. 80:89194

78. Reimman C, Maurhofer M, Schmidli P, Gaille C, Haas D, et al. 1997. Role of salicylate produced by Pseudomonas fluorescens in the suppression of tobacco diseases. See Ref. 72a, pp. 248-50

79. Ross AF. 1961. Localized acquired resistance to plant virus infection in hypersensitive hosts. Virology 14:329-39

80. Ross AF. 1961. Systemic acquired resistance induced by localized virus infections in plants. Virology 14:340-58

81. Rovira AD, Davey CB. 1974. Biology of the rhizosphere. In The Plant Root and its Environment, ed. EW Carson, pp. 153204. Charlottesville: Univ. Press VA

81a. Ryals J, Weymann K, Lawton K, Friedrich L, Ellis D, et al. 1997. The Arabidopsis NIM1 protein shows homology to the mammalian transcription factor inhibitor I $\kappa$ B. Plant Cell 9:425-39

82. Ryals JA, Neuenschwander UH, Willits MG, Molina A, Steiner HY, et al. 1996. Systemic acquired resistance. Plant Cell 8:1809-19

83. Schippers B. 1988. Biological control of pathogens with rhizobacteria. Phil. Trans. R. Soc. London B 318:283-93

84. Schippers B, Bakker AW, Bakker PAHM. 1987. Interactions of deleterious and beneficial rhizosphere microorganisms and the effect of cropping practices. Аnnu. Rev. Phytopathol. 25:339-58

85. Serino L, Reimmann C, Baur H, Beyeler $\mathrm{M}$, Visca P, et al. 1995. Structural genes for salicylate biosynthesis from chorismate in Pseudomonas aeruginosa. Mol. Gen. Genet. 249:217-28

86. Shah J, Tsui F, Klessig DF. 1997. Characterization of a salicylic acid-insensitive mutant (sail) of Arabidopsis thaliana, identified in a selective screen utilizing the SA-inducible expression of the tms 2 gene. Mol. Plant-Microbe Interact. 10:69-78

87. Staswick PE, Su W, Howell SH. 1992. Methyl jasmonate inhibition of root growth and induction of a leaf protein are decreased in an Arabidopsis thaliana mu- tant. Proc. Natl. Acad. Sci. USA 89:683740

88. Steiner U, Schönbeck F. 1995. Induced disease resistance in monocots. See Ref. 33 , pp. 86-110

89. Sticher L, Mauch-Mani B, Métraux JP. 1997. Systemic acquired resistance. Annu. Rev. Phytopathol. 35:235-70

90. Ton J, Pieterse CMJ, Van Loon LC. 1997. Genetic analysis of induced systemic resistance in Arabidopsis thaliana: association between induced systemic resistance and basal resistance. Proc. IOBC/EFPP Workshop: Mol. Approaches Biol. Control, 5th, Delémont. In press

91. Troxler J, Berling CH, Moënne-Loccoz Y, Keel C, Défago G. 1997. Interactions between the biocontrol agent Pseudomonas fluorescens $\mathrm{CHA} 0$ and Thielaviopsis basicola in tobacco roots observed by immunofluorescence microscopy. Plant Pathol. 46:62-71

92. Tsai FY, Hung KT, Kao CH. 1996. An increase in ethylene sensitivity is associated with jasmonate-promoted senescence of detached rice leaves. J. Plant Growth Regul. 154:197-200

93. Tuzun S, Kloepper J. 1995. Practical application and implementation of induced resistance. See Ref. 33, pp. 152-68

94. Tuzun S, Kuc J. 1987. Persistence of induced systemic resistance to blue mold in tobacco plants derived via tissue culture. Phytopathology 77:1032-35

95. Uknes S, Mauch-Mani B, Moyer M, Potter S, Williams S, et al. 1992. Acquired resistance in Arabidopsis. Plant Cell 4:64556

96. Van Loon LC. 1997. Induced resistance in plants and the role of pathogenesis-related proteins. Eur. J. Plant Pathol. 103:753-65

97. Van Loon LC, Antoniw JF. 1982. Comparison of the effects of salicylic acid and ethephon with virus-induced hypersensitivity and acquired resistance in tobacco. Neth. J. Plant Pathol. 88:237-56

98. Van Peer R, Niemann GJ, Schippers B. 1991. Induced resistance and phytoalexin accumulation in biological control of fusarium wilt of carnation by Pseudomonas sp. strain WCS417r. Phytopathology 81:728-34

99. Van Peer R, Schippers B. 1992. Lipopolysaccharides of plant-growth promoting Pseudomonas sp. strain WCS417r induce resistance in carnation to fusarium wilt. Neth. J. Plant Pathol. 98:129-39

100. Van Wees SCM, Pieterse CMJ, Trijssenaar A, Van 't Westende Y, Hartog F, et al. 1997. Differential induction of systemic resistance in Arabidopsis by bio- 
control bacteria. Mol. Plant-Microbe Interact. 10:716-24

101. Vernooij B, Friedrich L, Morse A, Reist R, Kolditz-Jawhar R, et al. 1994. Salicylic acid is not the translocated signal responsible for inducing systemic acquired resistance but is required in signal transduction. Plant Cell 6:959-65

102. Ward ER, Uknes SJ, Williams SC, Dincher SS, Wiederhold DL, et al. 1991. Coordinate gene activity in response to agents that induce systemic acquired resistance. Plant Cell 3:1085-94

103. Wasternack C, Parthier B. 1997. Jasmonate-signalled plant gene expression. Trends Plant Sci. 2:302-7

104. Wei G, Kloepper JW, Tuzun S. 1991. Induction of systemic resistance of cucumber to Colletotrichum orbiculare by select strains of plant growth-promoting rhizobacteria. Phytopathology 81:1508-12

105. Wei G, Kloepper JW, Tuzun S. 1992. Internal and external colonization of cucumber by bacteria which induce systemic resistance to Colletotrichum orbiculare. Phytopathology 2:1108 (Abstr.)

106. Wei G, Kloepper JW, Tuzun S. 1996. Induced systemic resistance to cucumber diseases and increased plant growth by plant growth-promoting rhizobacteria under field conditions. Phytopathology $86: 221-24$
107. Weller DM. 1988. Biological control of soil-borne plant pathogens in the rhizosphere with bacteria. Annu. Rev. Phytopathol. 26:379-407

108. Xu Y, Chang PFL, Liu D, Narasimhan ML, Raghothama KG, et al. 1994. Plant defense genes are synergistically induced by ethylene and methyl jasmonate. Plant Cell 6:1077-85

109. Zdor RE, Anderson AJ. 1992. Influence of root colonizing bacteria on the defense responses of bean. Plant Soil 140:99107

110. Zehnder G, Kloepper J, Tuzun S, Yao C, Wei G, et al. 1997. Insect feeding on cucumber mediated by rhizobacteriainduced plant resistance. Entomol. Exp. Appl. 83:81-85

111. Zehnder G, Kloepper J, Yao CB, Wei G. 1997. Induction of systemic resistance in cucumber against cucumber beetles (Coleoptera: Chrysomelidae) by plant growth-promoting rhizobacteria. J. Econ. Entomol. 90:391-96

112. Zhang W, Dick WA, Hoitink HAJ. 1996. Compost-induced systemic acquired resistance in cucumber to Pythium root rot and anthracnose. Phytopathology 86:1066-70

113. Zhou T, Paulitz TC. 1994. Induced resistance in the biocontrol of Pythium aphanidermatum by Pseudomonas spp. on cucumber. J. Phytopathol. 142:51-63 